\title{
Phytotoxic potential of young leaves from Blepharocalyx salicifolius (Kunth) O. Berg (Myrtaceae)
}

\author{
E. Habermann ${ }^{a *}$, F. C. Pontes $^{b}$, V. C. Pereira ${ }^{b}$, M. Imatomi ${ }^{b}$ S. C. J. Gualtieri ${ }^{b}$ \\ ${ }^{a}$ Grupo de Pesquisa em Ecofisiologia de Plantas Tropicais, Laboratório de Fisiologia Vegetal, \\ Departamento de Biologia, Faculdade de Filosofia, Ciências e Letras de Ribeirão Preto, \\ Universidade de São Paulo - USP, Av. Bandeirantes, 3900, CEP 14040-901, Monte Alegre, Ribeirão Preto, SP, Brazil

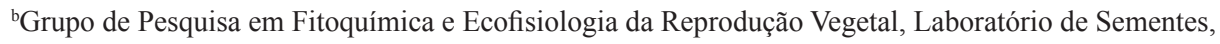 \\ Departamento de Botânica, Centro de Ciências Biológicas e da Saúde, Universidade Federal de São Carlos - UFSCar, \\ Rodovia Washington Luís, Km 235, CP 676, CEP 13565-905, São Carlos, SP, Brazil
}

*e-mail: eduardohabermann@gmail.com

Received: November 20, 2014 - Accepted: January 14, 2015 - Distributed: May 31, 2016

(With 6 figures)

\begin{abstract}
The loss of leaves by plant species found in the Cerrado (Brazilian savanna) is an energetically expensive process due to adverse environmental conditions and predation by herbivory. The mature leaves have adaptations which minimize these events. However, the young individuals lack these structures and produce high leaf concentrations of secondary metabolites as a form of protection. These compounds can be used in bioprospection of natural herbicides. Thus, this study aimed to evaluate the phytotoxicity of hexane, ethyl acetate and aqueous extracts of young leaves from Blepharocalyx salicifolius (Kunth) O. Berg on the elongation of wheat coleoptiles (Triticum aestivum L.) and evaluate the potential phytotoxic of ethyl acetate extract on germination, growth and cell size of metaxylem of sesame (Sesamum indicum L.) seedlings. The hexane and ethyl acetate extracts inhibited the elongation of wheat coleoptiles at all concentrations; however, the most promising results were observed in coleoptile fragments treated with the ethyl acetate extract. This treatment changed the mean germination time and the synchrony of sesame seeds, inhibited the growth of shoots and roots, reduced the dry weight of seedlings, led to abnormalities in the seedlings and reduced the length of the metaxylem cells in the sesame seedlings. These results demonstrated the phytotoxic potential of young leaf extracts of $B$. salicifolius and the high phytotoxicity of the ethyl acetate extract in the initial development of S. indicum.
\end{abstract}

Keywords: Triticum aestivum, Sesamum indicum, murta, allelopathy, bioactivity.

\section{Potencial fitotóxico de folhas jovens de Blepharocalyx salicifolius (Kunth) O. Berg}

\section{Resumo}

A perda das folhas pelas plantas do Cerrado é um processo energeticamente custoso devido às condições ambientais adversas e intensa predação por herbivoria. As folhas maduras possuem adaptações que minimizam esses eventos. Entretanto, os indivíduos jovens carecem dessas estruturas e produzem elevadas concentrações foliares de metabólitos secundários como forma de proteção. Esses compostos podem ser utilizados na bioprospecção de herbicidas naturais. Dessa forma, objetivamos com este estudo avaliar a fitotoxicidade dos extratos hexânico, acetato etílico e aquoso de folhas jovens de Blepharocalyx salicifolius (Kunth) O. Berg sobre o alongamento de coleóptilos estiolados de Triticum aestivum L. (trigo) e avaliar o potencial fitotóxico do extrato acetato etílico sobre a germinação, crescimento e comprimento das células do metaxilema de Sesamum indicum (gergelim). Os extratos hexânico e acetato etílico inibiram o alongamento dos coleóptilos em todas as concentrações testadas, entretanto os resultados mais promissores foram observados nos fragmentos submetidos ao extrato acetato etílico. Este extrato alterou o tempo médio de germinação e a sincronia das sementes de gergelim, inibiu o crescimento da parte aérea e subterrânea com redução da massa seca das plântulas, levou ao surgimento acentuado de anomalias e causou redução no comprimento médio das células do metaxilema de plântulas de gergelim. Assim, ficou comprovado o potencial fitotóxico dos extratos de folhas jovens de $B$. salicifolius e a acentuada fitotoxicidade do extrato acetato etílico sobre o desenvolvimento inicial de $S$. indicum.

Palavras-chave: Triticum aestivum, Sesamum indicum, murta, alelopatia, bioatividade. 


\section{Introduction}

Plant species produce a series of compounds derived from secondary metabolism (Rice, 1984) that are used in defense against herbivores and pathogen attacks (Baldwin et al., 1997; Chaves and Escudero, 1999). The qualitative and quantitative production of these substances depends on factors such as the plant's age and stress situations (Gobbo-Neto and Lopes, 2007). These metabolites may be present in any organ and can be released into the environment by volatilization; leaching of the aerial parts; decomposition of leaves, bark and fruits; and root exudation (Ferreira and Borghetti, 2004)

Such metabolites can alter the physiology of germination and growth of the target species (Zeng et al., 2010), thus modifying the composition of the surrounding plants (Ferreira, 2005) and soil microbes (Souza et al., 2006), which is important in the process of ecological succession (Reigosa et al., 1999). This chemical interaction mediated by secondary metabolites is known as allelopathy (Rice, 1984). Several classes of substances, such as coumarins, phenols, quinones, flavonoids and terpenes, have phytotoxic activity (Macías et al., 2003).

In the Cerrado (Brazilian savanna), the plants are subjected to water stress conditions, soil with excessive amounts of aluminum and acidic $\mathrm{pH}$, forest fires (Coutinho, 2000) and severe competition for resources (Imatomi et al., 2013). Thus, the loss of leaves and other parts is energetically expensive (Fine et al., 2006), and adaptations, such as coriaceous leaves, thorns and trichomes, have emerged to minimize predation events (OliverosBastida, 2008). However, the young leaves lack these defense mechanisms and produce high concentrations of secondary metabolites (Hartmann, 1996) to compensate for the absence of these structures.

Blepharocalyx salicifolius (Kunth) O. Berg (murta) belongs to Myrtaceae family found in the Cerrado (Brazilian savanna) (Denardi and Marchiori, 2005; Rego et al., 2010). The leaves of B. salicifolius have know leishimanicidal, antioxidant, antifungal, antimastite, antitumor and anti-inflammatory properties (Ceron et al., 2006; Siqueira et al., 2011; Vivot et al., 2012; Limberger et al., 2001). The phytotoxic potential of the leaf aqueous extracts of this species on bioindicators is also documented in the literature (Alves et al., 2014; Mairesse et al., 2007; Imatomi et al., 2013); however, studies evaluating phytotoxicity of extracts from young leaves in different polarities using organic solvents have not been reported in the literature.

Thus, this study aims to evaluate the phytotoxic potential of hexane, ethyl acetate and aqueous extracts of young leaves of Blepharocalyx salicifolius (Kunth) O. Berg on the elongation of wheat coleoptile and to test the phytotoxicity of ethyl acetate extract on the germination, growth and size of the metaxylem cells of sesame seedlings.

\section{Material and Methods}

\subsection{Plant materials}

Young leaves of Blepharocalyx salicifolius (Kunth) O. Berg were collected in the Cerrado (Brazilian savanna) area of the Universidade Federal de São Carlos (21 ${ }^{\circ} 58^{\prime} 5^{\prime \prime} \mathrm{S}$ and $47^{\circ} 53^{\prime} 12^{\prime \prime} \mathrm{W}$ ) in September 2012. According to Köeppen (1948), this region has the Aw climate type, with a wet summer and dry winter. Young leaves were considered those pale green in color with no membranous texture. The leaves were washed, dried in a forced air circulator at $40{ }^{\circ} \mathrm{C}$ for $72 \mathrm{~h}$ and ground in an electric mill to obtain leaf powder (Alves et al., 2014). The target species used were wheat coleoptiles (Triticum aestivum L. cv. BRS264) and sesame (Sesamum indicum L.) seeds and seedlings.

\subsection{Extraction}

The powder of young leaves was subjected to extraction with $\mathrm{CH}_{2} \mathrm{Cl}_{2} / \mathrm{CH}_{3} \mathrm{OH}(1: 1)$ in an ultrasonic bath (Rostagno et al., 2003). The dry extract was diluted in $\mathrm{H}_{3} \mathrm{OH} / \mathrm{H}_{2} \mathrm{O}(95: 5)$ and partitioned with hexane, resulting in the hexane and methanol extracts. Once dried, the methanol extract was diluted in distilled water and partitioned with ethyl acetate to produce the ethyl acetate and aqueous extracts (Otsuka, 2005).

\subsection{Bioassay assessment of wheat coleoptile elongation}

The extracts were used in the bioassay of etiolated wheat coleoptiles. To perform this experiment, Triticum aestivum etiolated coleoptiles, obtained from seedlings grown in water for three days under $25^{\circ} \mathrm{C}$ in the absence of light, were cut into $4 \mathrm{~mm}$ lenght fragments with a Van Der Veij guillotine under a green safety light. The apical $2 \mathrm{~mm}$ of each coleoptile was discarded (Hancock et al., 1964).

The extracts were solubilized in phosphate-citrate buffer solution containing $2 \%$ of sucrose ( $\mathrm{pH} 5.6)$ and DMSO $(5 \mu \mathrm{l} / \mathrm{mL})$ at concentrations of $0.2,0.4$ and $0.8 \mathrm{mg} \cdot \mathrm{mL}^{-1}$. A negative control with buffer and DMSO $(5 \mu \mathrm{l} / \mathrm{mL})$ and a positive control with $\mathrm{GOAL}^{\circledR}{ }^{\circledR}$ commercial herbicide (active ingredient oxyfluorfen $=240 \mathrm{~g} / \mathrm{L}$ ) and DMSO $(5 \mu \mathrm{l} / \mathrm{mL})$ at the same concentrations of the extract were used. The experiment was performed in triplicate with 5 coleoptile fragments and $2 \mathrm{~mL}$ of extract, control solution or oxyfluorfen. The tubes were kept in continuous rotation at $3 \mathrm{rpm}$ for $24 \mathrm{~h}$ in the dark at $25^{\circ} \mathrm{C}$ (Macías et al., 2010). Subsequently, the coleoptiles were removed, photographed and the lengths were measured using the Image-Pro Plus $5.0^{\circledR}$ (Media Cybernetics, Rockville, Maryland, USA) software.

\subsection{Germination bioassay}

Due to the inhibition results observed in the bioassay of wheat coleoptiles, the ethyl acetate extract was chosen for more detailed studies and tested for phytotoxicity on the germination of sesame (Sesamum indicum). For this experiment, the extract was solubilized in distilled water and DMSO $(5 \mu \mathrm{l} / \mathrm{mL})$ at concentrations of $1.0,1.25,1.5$ and $2.0 \mathrm{mg} \cdot \mathrm{mL}^{-1}$. A negative control was made with distilled water and DMSO $(5 \mu \mathrm{l} / \mathrm{mL})$, and a positive control was 
made with oxyfluorfen and DMSO $(5 \mu 1 / \mathrm{mL})$ at the same concentrations of the extract. The test was conducted in a Petri dish $9 \mathrm{~cm}$ diameter that was lined with two sheets of filter paper moistened with the solution of extract, negative control or oxyfluorfen. The plates were incubated in a B.O.D germination chamber at $25{ }^{\circ} \mathrm{C}$ with a $12 \mathrm{~h}$ photoperiod (Anese et al., 2014). Readings were taken every $12 \mathrm{~h}$ until the germination stabilized. We considered germinated seeds those that showed the protrusion of some part of the embryo (Brasil, 2009). We evaluated the germination, mean germination time and synchrony (Ranal and Santana, 2006).

\subsection{Seedling growth bioassay}

For this experiment, sesame seeds were germinated in distilled water under ideal conditions, and when $2 \mathrm{~mm}$ radicle protrusions were visible, they were transferred to transparent plastic boxes lined with two sheets of filter paper moistened with extract, control solution or oxyfluorfen at the same concentrations used in the germination bioassay. The boxes were kept for 7 days in the B.O.D germination chamber under the same conditions as those of the germination test. Then, the length of the shoots and roots of the seedlings were measured using a digital caliper (Anese et al., 2014) and qualified for the presence of anomalies according to Brasil (2009). Next, a blade was used to separate the roots and aerial parts of the seedlings, which were placed in paper bags in an oven with forced air circulation and incubated at $50^{\circ} \mathrm{C}$ until the weight stabilized, to determine the dry mass.

\subsection{Metaxylem cell growth biossay}

The anatomical study of the metaxylem cells of the sesame seedlings was performed using seeds germinated in distilled water under ideal conditions. The bioassays were conducted in triplicate using transparent plastic boxes lined with two sheets of filter paper moistened with $6 \mathrm{~mL}$ of the extracts at concentrations of $1.0,1.25$, 1.5 and $2.0 \mathrm{mg} \cdot \mathrm{mL}^{-1}$ or a negative control. When $2 \mathrm{~mm}$ radicle protrusion were visible, the sesame seedlings, in boxes, were transferred to the B.O.D germination chambre under the same conditions used for the growth biossays (Anese et al., 2014).

Then, the seedlings were removed, and their roots were cut using a blade. The primary roots were placed in a solution of $70 \%$ ethanol and incubated at $40{ }^{\circ} \mathrm{C}$ for seven days. Next, the roots were washed with distilled water and treated with a $25 \% \mathrm{NaOH}$ solution for 2 days at $40{ }^{\circ} \mathrm{C}$ for clarification of the biological material (Gatti et al., 2010). Then, the roots were washed with distilled water and treated with a solution of Lacmóide for 24 hours at room temperature. Finally, the roots were removed from the dye, washed and dried. The material was prepared on microscope slides and covered with a drop of Apathy syrup. Later the biological material was fixed with a cover slip (Kraus and Arduin, 1997).

The slides were observed under an optical microscope (Olympus BX51) coupled with a camera (Sony CCD-IRIS).
Four primary roots from sesame seedlings grown in different concentrations of extract or control were used. Half the length of each root of the central cervical region was photographed and 10 central cells of the metaxylem were measured using Image Pro-Plus Software 5.0 ${ }^{\circledR}$ (Media Cybernetics, Rockville, Maryland, USA). Slides were observed at $20 \mathrm{X}$.

\subsection{Data analyzes}

Using Bioestat and Past (Hammer et al., 2001) softwares, the data were tested for normality (Shapiro-Wilk) and homogeneity. When both these assumptions were met, the analysis of variance (ANOVA) followed by the $t$ test (Lsd) were performed $(p<0.05)$. A lack of normality and/ or homogeneity required the use of the non-parametric KruskalWallis test followed by the Student-Newman-Keuls test.

\section{Results}

The hexane and ethyl acetate extracts significantly inhibited the elongation of the cells of wheat coleoptiles at all concentrations. The aqueous extract inhibited the elongation at concentrations of 0.4 and $0.8 \mathrm{mg} \cdot \mathrm{mL}^{-1}$ (see Figure 1).

The ethyl acetate extract did not affect the germination of sesame seeds. However, there was a significant change in the mean germination time at the concentration of $1.0 \mathrm{mg} \cdot \mathrm{mL}^{-1}$ of $1.21 \pm 0.11$ (control) to $1.53 \pm 0.21$ days $^{-1}$. An increase of $0.5 \mathrm{mg} \cdot \mathrm{mL}^{-1}$ in the extract concentration reduced the mean germination time by 0.08 days $^{-1}$. A significant reduction was observed in the synchrony of germination at all concentrations, with reductions of up to $34 \%$ (see Table 1), and an increase of $0.5 \mathrm{mg} \cdot \mathrm{mL}^{-1}$ in the extract concentration caused a decrease in synchrony of 0.06 during the germination process. The oxyfluorfen did not affect seed germination; however, it significantly changed the mean germination time and the synchrony of germination. With an increase of $0.5 \mathrm{mg} \cdot \mathrm{mL}^{-1}$ in the

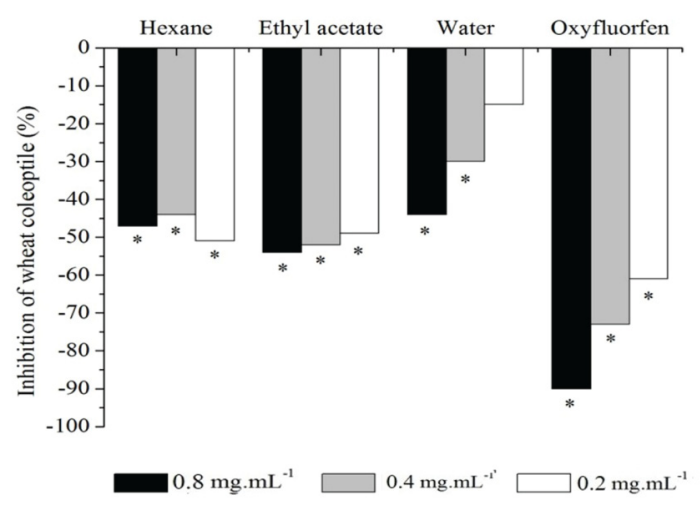

Figure 1. Percentage (\%) inhibition of the elongation of wheat coleoptiles in relation to the negative control, grown in substrate containing crude extracts of $B$. salicifolius and oxyfluorfen. $(*)$ Differs statistically from the negative control. 
oxyfluorfen concentration, the synchrony decreased by 0.1 (see Figure 2).

The ethyl acetate extract from young leaves inhibited the growth of sesame seedlings shoots from the concentration of $1.25 \mathrm{mg} \cdot \mathrm{mL}^{-1}$. A reduction of up to $39 \%$ in the size of this was observed. The root growth was inhibited sharply, with a linear decrease of $6.61 \mathrm{~mm}$ in the size of the roots for each increase of $0.5 \mathrm{mg} \cdot \mathrm{mL}^{-1}$ in extract concentration (see Figure 3; Figure 4). The growth inhibition was accompanied by a reduction in the dry weight of the seedlings of up to $15 \%$ for shoots and $41 \%$ for roots (see Table 1 ). The seedlings grown in contact with oxyfluorfen died and could not have their dry mass and metaxylem cell size measured.
The ethyl acetate extract led to abnormalities in the development of the sesame seedlings. At concentrations of 2.0 and $1.5 \mathrm{mg} \cdot \mathrm{mL}^{-1}, 100 \%$ of the seedlings showed some abnormality (see Table 1): severe atrophy of the stems, roots, leaves or absences of these parts; gravitropic inversion; and necrosis of the stems, roots or leaves. The reduction in root growth of the sesame seedlings was accompanied by a significant decrease in the metaxylem cell size at all concentrations. There was a $79.26 \mu \mathrm{m}$ $(38 \%)$ reduction in cell size at an extract concentration of $2.0 \mathrm{mg} \cdot \mathrm{mL}^{-1}$ (Figure 5). An increase of $0.5 \mathrm{mg} \cdot \mathrm{mL}^{-1}$ in extract concentration led to a $43.08 \mu \mathrm{m}$ reduction in the average length of cells (see Table 1, Figure 6). The correlation between the root growth of the sesame seedlings and the

Table 1. Parameters of germination, growth and metaxylem cell size of evaluated sesame seeds and seedlings that were treated with ethyl acetate extract of young leaves of B. salicifolius or oxyfluorfen. G: germination (\%); R: mean germination time $\left(\right.$ day $\left.^{-1}\right)$; Z: sync; S: mean shoot length (mm); R: mean root length (mm); A: abnormal seedlings (\%); MS: dry weight of shoots $(\mathrm{mg})$; MR: dry mass of roots $(\mathrm{mg})$; C: mean length of metaxylem cells $(\mu \mathrm{m})$. Different letters in the same row represent statistically significant differences $(\mathrm{p}<0.05)$. Mean \pm standard deviation.

\begin{tabular}{|c|c|c|c|c|c|}
\hline \multirow{2}{*}{ Variables } & \multicolumn{5}{|c|}{ Concentrations mg.mL $\mathrm{mL}^{-1}$} \\
\hline & $\mathbf{0}$ & 1.0 & 1.25 & 1.50 & 2.0 \\
\hline G & $96.66 \pm 6.66 \mathrm{a}$ & $92.50 \pm 6.30 \mathrm{a}$ & $95.83 \pm 5.0 \mathrm{a}$ & $92.50 \pm 4.19 \mathrm{a}$ & $92.50 \pm 5.0 \mathrm{a}$ \\
\hline $\mathbf{R}$ & $1.21 \pm 0.11 \mathrm{a}$ & $1.53 \pm 0.21 b$ & $1.47 \pm 0.10 \mathrm{a}$ & $1.46 \pm 0.08 \mathrm{a}$ & $1.47 \pm 0.13 \mathrm{a}$ \\
\hline $\mathbf{Z}$ & $0.70 \pm 0.07 \mathrm{a}$ & $0.46 \pm 0.09 b$ & $0.47 \pm 0.05 b$ & $0.48 \pm 0.03 b$ & $0.48 \pm 0.03 b$ \\
\hline $\mathbf{S}$ & $10.68 \pm 0.51 \mathrm{a}$ & $14.56 \pm 1.94 \mathrm{a}$ & $7.86 \pm 0.54 b$ & $8.75 \pm 2.15 b$ & $6.46 \pm 0.48 b$ \\
\hline $\mathbf{R}$ & $37.84 \pm 2.39 \mathrm{a}$ & $24.46 \pm 2.35 b$ & $19.89 \pm 2.45 b$ & $18.88 \pm 2.83 b$ & $11.18 \pm 0.60 \mathrm{~b}$ \\
\hline $\mathbf{A}$ & 0 & 12.5 & 22.5 & 100 & 100 \\
\hline MS & 71.6 & 67.1 & 60.8 & 66.7 & 64.5 \\
\hline MR & 33.0 & 24.9 & 19.6 & 22.7 & 31.5 \\
\hline \multirow[t]{2}{*}{$\mathbf{C}$} & $208.61 \pm 74.44 \mathrm{a}$ & $142.57 \pm 49.3 b$ & $147.52 \pm 56.5 b$ & $152.98 \pm 47.8 \mathrm{~b}$ & $129.35 \pm 47.5 b$ \\
\hline & \multicolumn{5}{|c|}{ Oxyfluorfen mg.mL $\mathrm{mL}^{-1}$} \\
\hline $\mathbf{G}$ & $96.66 \pm 6.66 \mathrm{a}$ & $86.66 \pm 11.22 \mathrm{a}$ & $100 \pm 3.19 \mathrm{a}$ & $92.50 \pm 1.66 \mathrm{a}$ & $84.16 \pm 9.95 a$ \\
\hline $\mathbf{R}$ & $1.21 \pm 0.11 \mathrm{a}$ & $2.65 \pm 0.51 b$ & $2.07 \pm 0.15 b$ & $2.39 \pm 0.10 \mathrm{~b}$ & $3.07 \pm 0.31 \mathrm{~b}$ \\
\hline $\mathbf{Z}$ & $0.70 \pm 0.07 \mathrm{a}$ & $0.36 \pm 0.07 b$ & $0.39 \pm 0.07 b$ & $0.34 \pm 0.05 b$ & $0.45 \pm 0.05 b$ \\
\hline
\end{tabular}
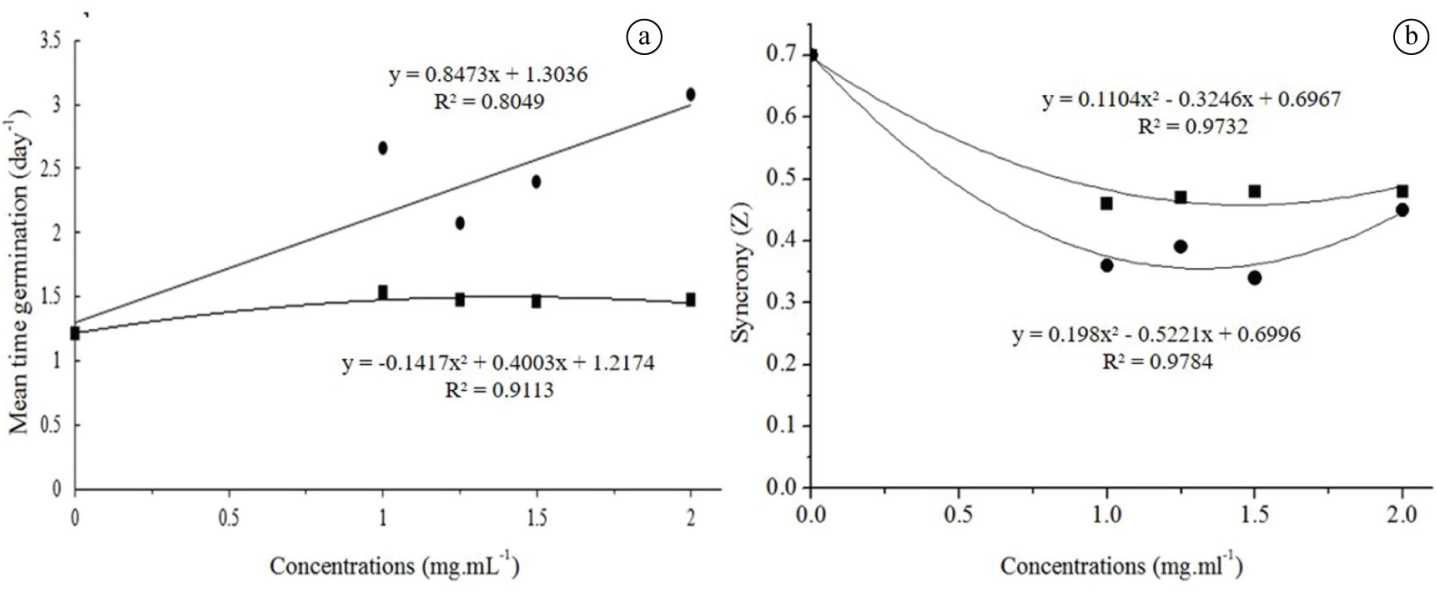

Ethyl acetate extract

Oxyfluorfen

Figure 2. (a) Mean germination time $\left(\right.$ day $\left.^{-1}\right)$ and (b) Sync of sesame seeds treated with the ethyl acetate extract of young leaves of $B$. salicifolius or oxyfluorfen. 
length of the metaxylem cells was $\mathrm{r}^{2}=0.8655$, indicating that the reduction of this organ is related to the decrease in metaxylem cell size.

\section{Discussion}

In this study, the ethyl acetate extract of young leaves of $B$. salicifolius showed the highest phytotoxic potential against the target species investigated. In work performed by An et al. (2000), the ethyl acetate fractions of the leaf extract of Vulpia myuros (Poaceae) were responsible for the highest inhibitory effects on the growth of Triticum aestivum (Poaceae). Flavonoids, such as quercitrin, were identified by Siqueira et al. (2011) from the ethanol extract of leaves of Blepharocalyx salicifolius (Myrtaceae). Quercitrin has phytotoxic activity (Iqbal et al., 2002) and may be related to the inhibitory results observed here. Still, the work carried out by Romero et al. (2012) and Suyenaga et al. (2007) identified phenolic compounds, anthraquinones, saponins and tannins in leaf extracts of $B$. salicifolius.

The mode of action of allelochemicals is extensive and is related to several metabolic processes such as

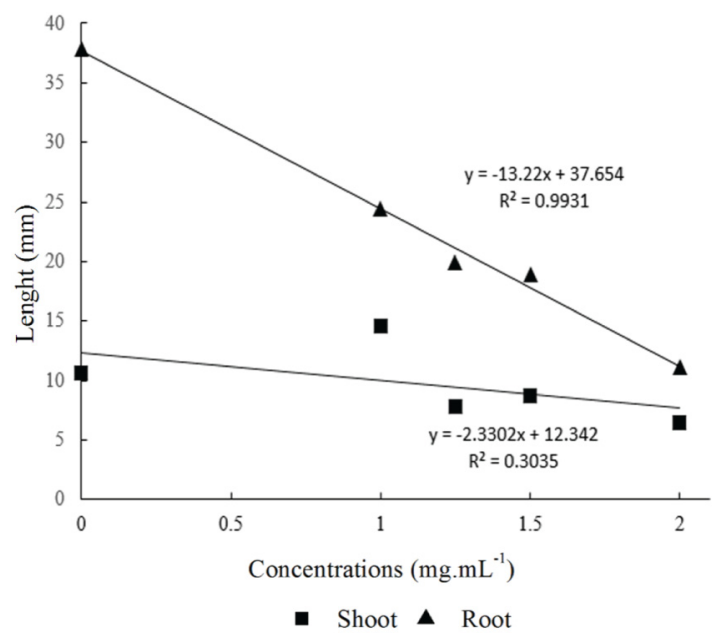

Figure 3. Mean length $(\mathrm{mm})$ of the shoots and roots of sesame seedlings grown in substrate containing the ethyl acetate extract of young leaves of $B$. salicifolius. photosynthesis, cellular respiration, hormonal balance, the depolarization and permeability of membranes affecting nutrient uptake, cell elongation and production of reactive oxygen species (ROS) (Gniazdowska and Bogatek, 2005; Al-Wakeel et al., 2007). These changes lead to physical and temporal modifications in the germination process through changes in the germinability, sync and mean time of germination and growth through development inhibition (Ferreira and Aquila, 2000; Oliveira et al., 2012). As observed by Pereira et al. (2014), these results indicated that the roots are more sensitive to phytotoxic than the hypocotyl. Root growth is characterized by high metabolic rates, and thus, this organ is very sensitive to environmental stress (Cruz-Ortega et al., 1998). Some authors suggest that this effect is pronounced due to the intimate contact between the root and the extract (Chung et al., 2001), changing the process of lignification of the cell walls (Suzuki et al., 2008). In a study by Anese et al. (2014), the aqueous extracts of mature leaves of Drimys brasiliensis (Winteraceae) obtained in different seasons showed marked inhibitory effects on seed germination and seedling growth of Sesamum indicum (Pedaliaceae).

Phytotoxic compounds can alter the morphology and anatomy of the receiving seedlings (Maraschin-Silva and Aquila, 2006). In this study, a high correlation between the size of the metaxylem cells and the mean length of the roots of sesame seedlings was observed. Similar results were reported by Moraes et al. (2014), in which the aqueous extracts of mature leaves and roots of Lafoensia glyptocarpa (Lythraceae) inhibited root growth, and this was correlated with a decrease in metaxylem cell size in Sesamum indicum (Pedaliaceae) seedlings. Auxin is responsible for controlling the process of cell elongation and growth and differentiation of primary and vascular tissues, such as metaxylem and protoxylem (Aloni et al., 2006). Furthermore, this hormone is responsible for leading various processes of root growth, such as tropic responses to light and gravity, the general architecture of plants and cell growth (Strader et al., 2010; Tanimoto, 2005).

The ethyl acetate extract changed the length of the metaxylem cells, the length of the seedlings and the plant architecture through abnormalities, indicating that the phytotoxic compounds in this extract may modify the

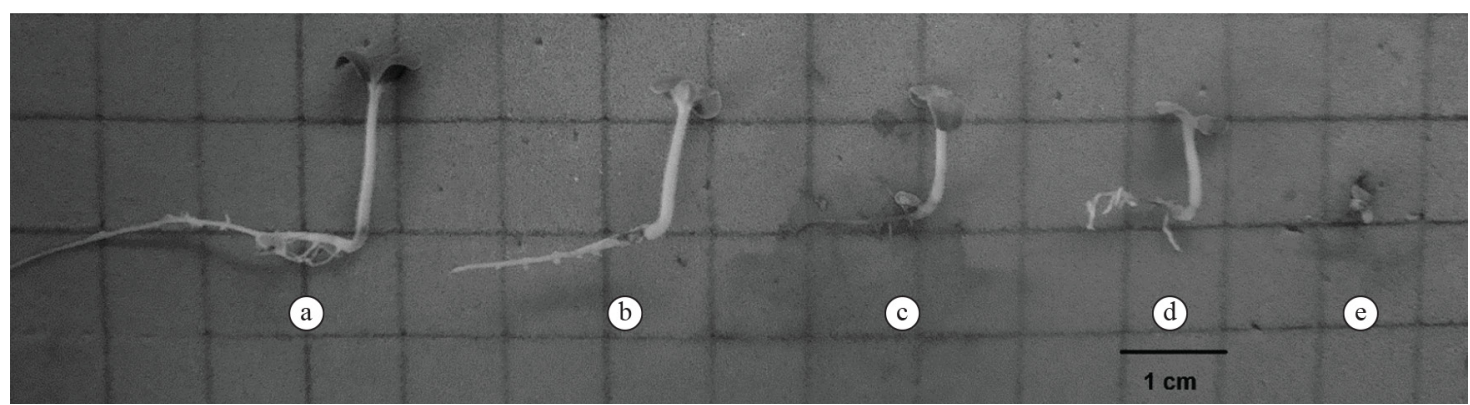

Figure 4. Sesame (S. indicum) seedlings grown in substrate containing (a) DMSO and distilled water (control) and DMSO and ethyl acetate extracts from young leaves of B. salicifolius at (b) 1.0, (c) 1.25, (d) 1.5 and (e) $2.0 \mathrm{mg} \cdot \mathrm{mL}^{-1}$. (Source: Elaborated by the authors). 

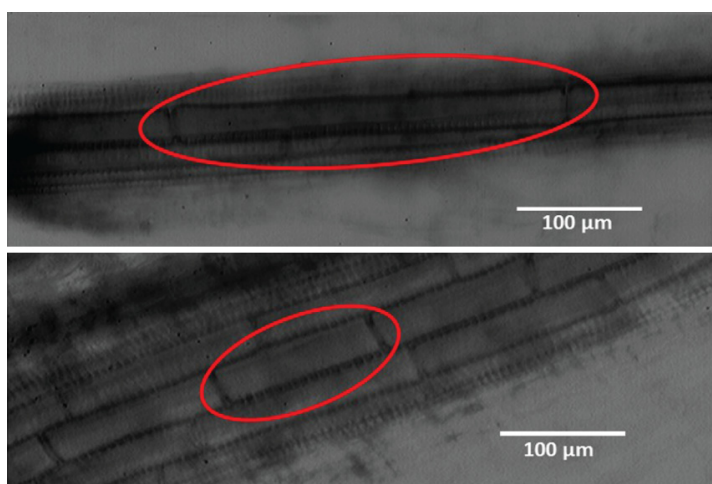

Figure 5. An optical microscope (magnification 20x) view of metaxylem cells obtained from roots of sesame seedlings grown in substrate containing: A: control solution and B: ethyl acetate extract of young leaves of B. salicifolius at concentration of $2.0 \mathrm{mg} \cdot \mathrm{mL}^{-1}$. The cells are highlighted with circles.

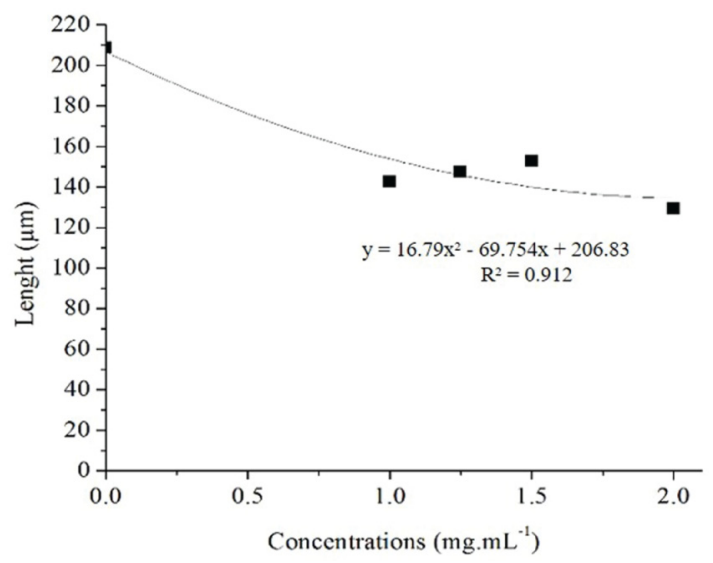

Figure 6. Mean length $(\mu \mathrm{m})$ of the metaxylem cells in the roots of sesame seedlings grown in substrate containing the ethyl acetate extract of young leaves of B. salicifolius.

action of plant hormones. Studies like this are important in discovering compounds with herbicide potential that can be used to control weed species, such as natural herbicides (Jamil et al., 2009), or when they are linked to conservation of native species and biomes.

This study demonstrates the phytotoxic potential of extracts from young leaves of $B$. salicifolius on the elongation of wheat coleoptile and the high phytotoxicity of ethyl acetate extract on the germination, growth and metaxylem cell elongation in sesame seedlings.

\section{Acknowledgements}

This work was supported by the Sao Paulo Research Foundation, FAPESP, Grant 2012/17714-3, CAPES and CNPq.

\section{References}

ALONI, R., ALONI, E., LANGHANS, M. and ULLRICH, C.I., 2006. Role of cytokinin and auxin in shaping root architecture: regulating vascular differentiation, lateral root initiation, root apical dominance and root gravitropism. Annals of Botany, vol. 97, no. 5, pp. 883-893. http://dx.doi.org/10.1093/aob/mcl027. PMid:16473866.

ALVES, A.P., FANTI, S.C., GUALTIERI, S.C.J., IMATOMI, M., HABERMANN, E. and CEVITHEREZA, F.P., 2014. Actividad fitotóxica de los extractos de hojas maduras de Blepharocalyx salicifolius Kuth. O. Berg. Revista Latinoamericana de Química, vol. 42 , no. 1 , pp. 133-142.

AL-WAKEEL, S.A.M., GABR, M.A., HAMID, A.A. and ABUEL-SOUD, W.M., 2007. Allelopathic effects of Acacia nilotica leaf residue on Pisum sativum L. Allelopathy Journal, vol. 19, no. 2, pp. 411-422.

AN, M., HAIG, T. and PRATLEY, J.E., 2000. Phytotoxicity of vulpia residues: ii. separation, identification, and quantitation of allelochemicals from Vulpia myuros. Journal of Chemical Ecology, vol. 26, no. 6, pp. 1465-1476. http://dx.doi. org/10.1023/A:1005539809774.

ANESE, S., GRISI, P.U., JATOBÁ, L.J., IMATOMI, M., PEREIRA, V.C. and GUALTIERI, S.C.J., 2014. Seasonal variation in phytotoxicity of Drimys brasiliensis Miers. Idesia, vol. 32, no. 3, pp. 109-116. http://dx.doi.org/10.4067/S0718-34292014000300014.

BALDWIN, I.T., ZHANG, Z.P., DIAB, N., OHNMEISS, T.E., MCCLOUD, E.S., LYNDS, Y.G. and SCHMELZ, E.A., 1997. Quantification, correlations, and manipulations of wound-induced changes in jasmonic acid and nicotine in Nicotiana sylvestris. Planta, vol. 201, no. 4, pp. 397-404. http://dx.doi.org/10.1007/ s004250050082.

BRASIL. MINISTÉRIO DA AGRICULTURA, PECUÁRIA E ABASTECIMENTO - MAPA, 2009. Regras para a análise de sementes. Brasília: MAPA.

CERON, C.S., ZANOTTO, C.Z., SILVEIRA, R.S., KUNZ, V.T., WALKER, C.I.B. and MANFRON, M.P., 2006. Atividade antioxidante dos extratos de Blepharocalyx salicifolius (H.B.K.) Berg. In: Anais do I Congresso de Farmácia de Maringá, 2006, Maringá. Maringá: ARQ MUDI.

CHAVES, N. and ESCUDERO, C., 1999. Variation of flavonoid syntheis induced by ecological factors. In: INDERJIT, K M.M. DAKSHINI, and C.L. FOY, eds. Principles and practices in plant ecology - allelochemical interactions. Boca Raton: CRC Press. pp. 267-285.

CHUNG, I.M., AHN, J.K. and YUN, S.J., 2001. Assesment of allelopathic potential of barnyard grass (Echinochloa crus-galli) on rice (Oriza sativa L.) cultivars. Crop Protection (Guildford, Surrey), vol. 20, no. 10, pp. 921-928. http://dx.doi.org/10.1016/ S0261-2194(01)00046-1.

COUTINHO, L.M., 2000. O bioma do cerrado. In A.L. KLEIN, ed. Eugen Warming e o cerrado brasileiro. São Paulo: UNESP. pp. 77-92.

CRUZ-ORTEGA, R., ANAYA, A.L., HERNÁNDEZ-BAUTISTA, B.E. and LAGUNA-HERNÁNDEZ, G., 1998. Effects of allelochemical stress produced by Sicyos deppei on seedling root ultrastructure of Phaseolus vulgaris and Cucurbita ficifolia. Journal of Chemical Ecology, vol. 24, no. 12, pp. 2039-2057. http://dx.doi.org/10.1023/A:1020733625727. 
DENARDI, L. and MARCHIORI, J.N.C., 2005. Anatomia ecológica da madeira de Blepharocalyx salicifolius (H.B.K) Berg. Ciência Florestal, vol. 15, no. 2, pp. 119-127.

FERREIRA, A.G. and ÁQUILA, M.E.A., 2000. Alelopatia: uma área emergente da ecofisiologia. Revista Brasileira de Fisiologia Vegetal, vol. 12, pp. 175-204. Special Issue.

FERREIRA, A.G. and BORGHETTI, F., 2004. Germinação: do básico ao aplicado. Porto Alegre: Artimed. 323 p.

FERREIRA, A.G., 2005. Alelopatia: sinergismo e inibição. In: R.J.M.C. NOGUEIRA, E.L. ARAÚJO, L.G. WILLADINO and U.M.T. CAVALCANTE, eds. Estresses ambientais: danos e beneficios em plantas. Recife: UFRPE. pp. 433-440.

FINE, P.V.A., MILLER, Z.J., MESONES, I., IRAZUZTA, S., APPEL, H.M., STEVENS, M.H.H., SÄÄKSJÄRVI, I., SCHULTZ, J.C. and COLEY, P.D., 2006. The growth-defense trade-off and habitat specialization by plants in Amazonian forests. Ecology, vol. 87, no. 7, suppl., pp. S150-S162. http://dx.doi.org/10.1890/00129658(2006)87[150:TGTAHS]2.0.CO;2. PMid:16922310.

GATTI, A.B., FERREIRA, A.G., ARDUIN, M. and PÉREZ, S.C.J.G.A., 2010. Allelopathic effects of aqueous extracts of Aristolochia esperanzae O. Kuntze on development of Sesamum indicum L. seedlings. Acta Botanica Brasílica, vol. 24, no. 2, pp. 454-461. http://dx.doi.org/10.1590/S0102-33062010000200016.

GNIAZDOWSKA, A. and BOGATEK, R., 2005. Allelopathic interactions between plants. Multi site action of allelochemicals. Acta Physiologiae Plantarum, vol. 27, no. 3, pp. 395-407. http:// dx.doi.org/10.1007/s11738-005-0017-3.

GOBBO-NETO, L. and LOPES, N.P., 2007. Plantas medicinais: fatores de influência no conteúdo de metabólitos secundários. Quimica Nova, vol.30, no. 2, pp. 374-381. http://dx.doi.org/10.1590/ S0100-40422007000200026.

HAMMER, Ø., HARPER, D.A.T. and RYAN, P.D., 2001. PAST: Paleontological statistics software package for education and data analysis. Palaeontologia Electronica, vol. 4, no. 1, pp. 1-9.

HANCOCK, C.R., BARLOW, H.W. and LACEY, H.J., 1964. The east malling coleoptile straight growth test method. Journal of Experimental Botany, vol. 15, no. 1, pp. 166-176. http://dx.doi. org $/ 10.1093 / \mathrm{j} \times \mathrm{b} / 15.1 .166$.

HARTMANN, T., 1996. Global harmonization of herbal health claims. Entomologia Experimentalis et Applicata, vol. 80, no. 1, pp. 177-179.

IMATOMI, M., NOVAES, P., MATOS, A.P., GUALTIERI, S.C.J., MOLINILLO, J.M.G., LACRET, R., VARELA, R.M. and MACÍAS, F.A., 2013. Phytotoxic effect of bioactive compounds isolated from Myrcia tomentosa (Myrtaceae) leaves. Biochemical Systematics and Ecology, vol. 46, pp. 29-35. http://dx.doi. org/10.1016/j.bse.2012.09.005.

IQBAL, Z., HIRADATE, S., NODA, A., ISOJIMA, S.-I. and FUJII, Y., 2002. Allelopathy of buckwheat: assessment of allelopathic potential of extract of aerial parts of buckwheat and identification of fagomine and other related alkaloids as "allelochemicals. Weed Biology and Management, vol. 2, no. 2, pp. 110-115. http://dx.doi. org/10.1046/j.1445-6664.2002.00055.x.

JAMIL, M., CHEEMA, Z.A., MUSHTAQ, M.N., FAROOQ, M. and CHEEMA, M.A., 2009. Alternative control of wild oat and canary grass in wheat fields by allelopathic plant water extracts. Agronomy for Sustainable Development, vol. 29, no. 3, pp. 475482. http://dx.doi.org/10.1051/agro/2009007.
KÖEPPEN, W., 1948. Climatologia com um estúdio de los climas de la tierra. México: Fondo de Cultura Economica. 479 p.

KRAUS, J.E. and ARDUIN, M., 1997. Manual básico de métodos em morfologia vegetal. Rio de Janeiro: EDUR. 198 p.

LIMBERGER, R.P., SOBRAL, M.E.G., ZUANAZZI, J.A.S., MORENO, P.R.H., SCHAPOVAL, E.E.S. and HENRIQUES, A.T., 2001. Biological activities and essential oil composition of leaves of Blepharocalyx salicifolius. Pharmaceutical Biology, vol. 39, no. 4, pp. 308-311. http://dx.doi.org/10.1076/phbi.39.4.308.5915.

MACÍAS, F.A., GALINDO, J.C.G., MOLINILLO, J.M.G. and CUTLER, H.G., 2003. Allelopathy: chemistry and mode of action of allelochemicals. Boca Raton: CRC Press. 392 p.

MACÍAS, F.A., LACRET, R., VARELA, R.M., NOGUEIRAS, C. and MOLINILLO, J.M.G., 2010. Isolation and phytotoxicity of terpenes from Tectona grandis. Journal of Chemical Ecology, vol. 36, no. 4, pp. 396-404. http://dx.doi.org/10.1007/s10886010-9769-3. PMid:20237951.

MAIRESSE, L.A.S., COSTA, E.C., FARIAS, J.R. and FIORIN, R.A., 2007. Bioatividade de extratos vegetais sobre alface (Lactuca sativa L.). Revista da FZVA, vol. 12, no. 2, pp. 1-12.

MARASCHIN-SILVA, F. and AQÜILA, M.E.A., 2006. Contribuição ao estudo do potencial alelopático de espécies nativas. Revista Árvore, vol. 30, no. 4, pp. 547-555. http://dx.doi.org/10.1590/ S0100-67622006000400007.

MORAES, L.P.S., GUALTIERI, S.C.J., LIMA, M.I.S., GATTI, A.B., PEREIRA, V.C. and MIRANDA, M.A.F.M., 2014. Efeitos alelopáticos de Lafoensia glyptocarpa Koehne sobre Sesamum indicum L. e sobre o crescimento de coleóptilos de Triticum aestivum L. Iheringia. Série Botânica, vol. 69, no. 1, pp. 37-48.

OLIVEIRA, A.K., COELHO, M.F.B., MAIA, S.S.S., DIÓGENES, F.E.P. and MEDEIROS FILHO, S., 2012. Alelopatia de extratos de diferentes órgãos de mulungu na germinação de alface. Horticultura Brasileira, vol. 30, no. 3, pp. 480-483. http://dx.doi. org/10.1590/S0102-05362012000300020.

OLIVEROS-BASTIDA, A.J., 2008. El fenómeno alelopático. El concepto, las estratégias de estudio y su aplicación em la búsqueda de herbicidas naturales. Química Viva, vol. 7, no. 1, pp. 1-34.

OTSUKA, H., 2005. Purification by solvent extraction using partition coefficient. In: S.D. SARKER, Z. LATIF and A.I. GRAY, eds. Natural products isolation. Methods in Biotechnology. New York: Humana Press, pp. 269-273.

PEREIRA, V.C., GRISI, P.U., DODONOV, P., ANESE, S. and GUALTIERI, S.C.J., 2014. Atividade fitotóxica de Serjania lethalis sobre a germinação e crescimento de Panicum maximum. Biotemas, vol. 27, no. 1, pp. 29-35.

RANAL, M.A. and SANTANA, D.G., 2006. How and why to measure the germination process? Revista Brasileira de Botanica. Brazilian Journal of Botany, vol. 29, no. 1, pp. 1-11. http://dx.doi. org/10.1590/S0100-84042006000100002.

REGO, S.S., NOGUEIRA, A.C., KUNIYOSHI, Y.S. and SANTOS, A.F.D., 2010. Caracterização morfológica do fruto, da semente e do desenvolvimento da plântula de Blepharocalyx salicifolius (H.B.K.) Berg. e Myrceugenia gertii Landrum - Myrtaceae. Revista Brasileira de Sementes, vol. 32, no. 3, pp. 52-60. http:// dx.doi.org/10.1590/S0101-31222010000300006.

REIGOSA, M.J., SÁNCHEZ-MOREIRAS, A. and GONZÁLEZ, L., 1999. Ecophysiological approach in allelopathy. Critical 
Reviews in Plant Sciences, vol. 18, no. 5, pp. 577-608. http:// dx.doi.org/10.1016/S0735-2689(99)00392-5.

RICE, E.L., 1984. Allelopathy. 2nd ed. Orlando: Academic Press. $422 \mathrm{p}$.

ROMERO, L.V., BOHNERT, C., SANTOS, I.D., RIGÃO, C.S., ZAGO, A.M., FROSI, M. and PIGATTO, A.G.S., 2012. Análise fitoquímica da murta: resultados preliminares. In: Anais do XVI Simpósio de Ensino, Pesquisa e Extensão (SEPE): Aprender e empreender na educação e na ciência, 2012, Santa Maria. Santa Maria: Unifra.

Rostagno, M.A., PALMA, M. and BARroso, C., 2003. Ultrasound-assisted extraction of soy isoflavones. Journal of Chromatography. A, vol. 1012, no. 2, pp. 119-128. http://dx.doi. org/10.1016/S0021-9673(03)01184-1. PMid:14521308.

SIQUEIRA, E.P., OLIVEIRA, D.M., JOHANN, S., CISALPINO, P.S., COTA, B.B., RABELLO, A., ALVES, T.M.A. and ZANI, C.L., 2011. Bioactivity of the compounds isolated from Blepharocalyx salicifolius. Revista Brasileira de Farmacognosia, vol. 21, no. 4, pp. 645-651. http://dx.doi.org/10.1590/S0102-695X2011005000111.

SOUZA, L.S., VELINI, E.D., MARTINS, D. and ROSOLEM, C.A., 2006. Efeito alelopático de capim-braquiária (Brachiaria decumbens) sobre o crescimento inicial de sete espécies de plantas cultivadas. Planta Daninha, vol. 24, no. 4, pp. 657-668. http:// dx.doi.org/10.1590/S0100-83582006000400006.
STRADER, L.C., CHEN, G.L. and BARTEL, B., 2010. Ethylene directs auxin to control root cell expansion. The Plant Journal, vol. 64, no. 5, pp. 874-884. http://dx.doi.org/10.1111/j.1365313X.2010.04373.x. PMid:21105933.

SUYENAGA, E.S., SANTOS, L.R., MARTINS, L.S. and BUENO, F., 2007. O risco de plantas medicinais indicadas por ervateiros no tratamento da sinusite em Porto Alegre. Estudos, vol. 34, no. 6, pp. 833-842.

SUZUKI, L.S., ZONETTI, P.C., FERRARESE, M.L.L. and FERRAREZE-FILHO, O., 2008. Effects of ferulic acid on growth and lignification of convencional and glyphosate-resistant soybean. Allelopathy Journal, vol. 21, no. 1, pp. 155-154.

TANIMOTO, E., 2005. Regulation of root growth by plant hormones: Roles for auxin and gibberellin. Critical Reviews in Plant Sciences, vol. 24, no. 4, pp. 249-265. http://dx.doi. org/10.1080/07352680500196108.

VIVOT, E.P., SÁNCHEZ, C., CACIK, F. and SEQUIN, C., 2012. Actividad antibacteriana em plantas medicinales de la flora de Entre Ríos (Argentina). Ciencia, Docencia y Technologia, vol. 23 , no. 45 , pp. 165-185.

ZENG, R.S., MALLIK, A.U. and LUO, S., 2010. Allelopathy in sustainable agriculture and forestry. New York: Springer Verlag. $426 \mathrm{p}$. 